\title{
PSYCHE
}

VOL. XVIII.

APRIL, 1911.

No. 2

\section{A REVISION OF THE NORTH AMERICAN SPECIES OF THE DIPTEROUS GENUS HYDROPHORUS.}

\author{
BY J. M. AlLDRiCH.
}

The University of Idaho, Moscow, Idaho.

The genus Hydrophorus, established by Fallén in 1823, as limited by Loew in 1857, as generally used since and as herein understood, comprises those flies of the family Dolichopodidæ which have the posterior crossvein located near the hind margin of the wing (distant about its own length, measured on the fifth vein); fourth vein ending in or behind the apex (this excludes Scellus, in which it ends before the apex); front femora thickened (this excludes Liancalus), more or less spinose beneath; dorsum of thorax not with a concave or flattened space before the scutellum (excludes Medeterus); and with the usual single row of postorbital small bristles replaced below with a loose tuft of pale hairs covering all the posterior surface of the head below the neck.

The species are rather small, from 2.5 to about $6 \mathrm{~mm}$. in length. The adults are always found close to the edge of water on wet earth, or else running on the surface of the water. They are carnivorous, seizing smaller flies, etc., and holding them with their raptorial front legs while they suck out the juices. The larvæ have not been reported to my knowledge, but it is almost certain that they live in mud at the edge of water.

The adults have a wide range of season, as will be indicated by the dates cited in connection with the descriptions. Considering the fact that several species can easily be found in any locality, the genus has been little collected. This is partly due to the lack of those conspicuous male characters which render some other Dolichopodidæ so interesting, and partly to a general similarity of appearance which has made the taxonomy of the genus comparatively unattractive. Howerer, in the following 
pages it will appear that nothing but a closer study is needed (especially with the new binocular dissecting microscopes) to find characters almost if not quite as interesting as those of Dolichopus.

The North American species were so little known at the time of Locw's monograph of the family that he could describe only three species, to which he afterward added two in the later part of his Centuries. The principal contribution to the genus since that time has been by Wheeler (Proc. California Acad. Sciences, 3rd ser. Zool. Vol. II, pp. 62-69, 1899) in which a table of specics is given, five new species described, and numerous excellent figures published, showing especially the spinulation of the front femur and tibia, which had been but little appreciated before.

Walker described four species in this genus, of which I think I recognize chrysologus, which had before been identified with his name glaber; the rest are mentioned at the end of this paper. Say's Medeterus lateralis I consider to be a Neurigona, and his punctipennis to be a Pelastoneurus.

Bibliographic references are given herein only where they correct or add to those of my Catalogue, now generally accessible.

A few suggestions about specific characters in the genus will doubtless be of use to those who undertake to determine specimens.

A highly interesting and heretofore unreported character is the presence in thrce of our species of a row of bristles across the occiput (fig. 4); as the usual pair of postvertical bristles are included in the row, I have referred to them all by that term. The black bristles which form a row behind the upper part of the eye I have termed the postorbitals; they extend much farther down in some species than in others. Beneath the neck among the pale hairs called the beard are sometimes several black bristles; they are too hard to see to be of much importance in classification, but I have mentioned their occurrence when I could see them. The width of the check at the lower edge of the eye is an important character, but it is clifficult to measure it by anything very tangible; the student will need to gain his ideas by comparing several species. The metallic color of the face, and its alternative, the complete opacity of the face, might not seem to sound very definite, but I think they work out very well. I find hardly a species difficult to place by this character. The antenna 
generally are of little diagnostic value. They are always wholly black, except in some cases where there may be a whitish tip to the arista, which I do not find worth mentioning; in a few species the first joint of the antemua is elongated, and in cerutias, especially the male, there is a remarkable elongation of the whole organ (fig. 5). The width of the face and the color of the palpi are occasionally unusual and useful.

The thorax presents many opportunities for distinguishing species, especially in its chætotaxy. The scutellar bristles are uniformly four except in gratiosus (2), intentus (6), plumbeus (10), and cerutias (2). The numbers above four may be expected to be a little variable. The notopleurals are generally two, but are only one in gratiosus, intentus, plumbeus, cerutias and agalma. Not to prolong the list too much, the dorsocentrals vary in their size, some species having them large and others small; one species, canescens, has them white, a striking feature. The propleural (just above the front coxa on the side) shows some interesting changes; in plumbeus there are several, in all the rest one except cerutias, canescens and agalma, which have none; in phoca, the single propleural is yellow instead of black. The pleura often has fine, pale hairs in noticeable clusters in very definite spots, which I have mentioned in many cases. The halteres may be wholly yellow, or the knob may be more or less infuscated, and these two alternatives divide the genus more naturally than any other I can find, hence I have made primary use of them in my table. The wings offer few valuable characters. One of the first class is found in cerutias, but was overlooked by Loew-the extreme shortness of the second vein (fig 1). No other North American species has this peculiarity. The two spots on the wing in a few species are very constant, but other species have them in a very faint degree, also constant, which makes the character unavailable in a table except in one group. The paleness of the veins at the base is rather variable and I have found it of little use except in a few species. The abdomen presents very few salient characters. The hypopygium of the male varies so much in drying that it is almost impossible to make any use of it, while in other Dolichopod genera it is often of the greatest use and value. The legs except the front ones offer few characters. I have paid considerable attention to 
the small black bristles of the front coxæ; while they are somewhat inconstant, they yield some good distinguishing marks. The front femora have on the under side some short stiff spines, against which the tibia closes with its row of spinules, thus holding the prey while it is devoured. This arrangement is repeated in many slightly varying forms in the different species, but in three, canescens, amplectens and breviseta, a secondary modification has taken place in the male, furnishing special grasping organs which must be for the purpose of holding the female, since they are confined to the male sex; in amplectens it is a question if the second function has not superseded the first. The middle and hind legs offer a few slight and one (breviseta) rather striking ornamental or other male characters.

In the measurements I have included the length of the wing, as the abdomen shrivels to such a variable extent that the length of the body becomes untrustworthy except in a general way.

Table of Species.

1. Knobs of halteres yellow.........................

Knobs of halteres infuscated, at least on outer side. . . . . . . . . . . . 13

2. Postvertical bristles in a row of six or more (fig. 4) $\ldots \ldots \ldots \ldots \ldots \ldots \ldots$

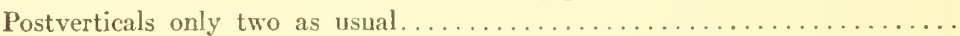

3. Scutellar bristles one pair................. gratiosus sp. nov.

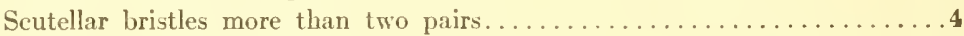

4. Propleural bristles several.................. plumbeus sp. nov. Propleural bristles (black) none or only one........... intentus sp. nov.

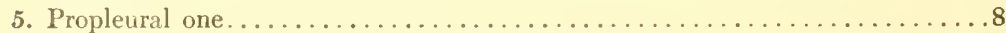

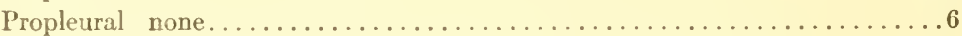

6. Second longitudinal very short, ending opposite hind crossvein (fig. 1).

cerutias Loew.

Second vein normal, much longer (figs. 2, 3)..................

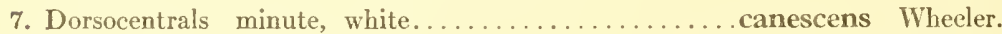

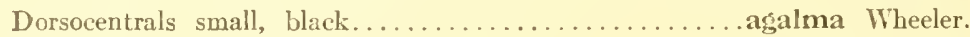

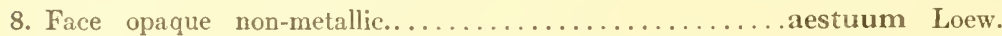

Metallic color visible on upper part of face.................

9. Tip of front tibia in both sexes with an acute angle produced toward the femur (one to three bristles on upper outer corner of front coxa, and the face generally very bright blue-green as far down as the suture $\ldots \ldots \ldots \ldots \ldots \ldots \ldots \ldots \ldots$ philombrius

Tip of fore tibia not or but slightly angulated toward the femur (face not shining so far down, generally no bristles on basal part of front coxa).

Wheeler.

10. Front tibia of male notched on inner side at two-thirds its length 
CORRECTIONS TO THE TABLE OF SPECIES OF HYDROPHORUS,

Pp. 48-49. (Psyche, April, 1911.)

1. Knob of halteres yellow ...................... . .

Knob of halteres infuscated, at least on outer side ............ 12

2. Postvertical bristles in a row of six or more (fig. 4 ) . . . . . . . . . . . 3

Postvertical bristles only two as usual . . . . . . . . . . . . . .

In the first part of couplet 12 , where the number 1 oceurs at the right it should be 13 . 
(fig. 10 .

breviseta Thomson.

Front tibia not notched. . . . . . . . . . . . . . . . . . . . 11

11. Size $3 \mathrm{~mm}$.; pleura with rather thick white pruinosity.... sodalis Wheeler.

Size $4.5 \mathrm{~mm}$.; pleura with thin yellowish pruinosity. ... magdalenæ Wheeler.

12. Wing with a brown spot on the middle of the last section

of the fourth vein, and another on the hind crossvein (fig. 2) . . . . . . . .

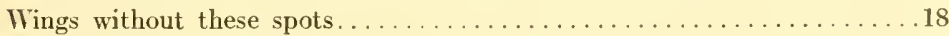

13. Face opaque non-metallic........................ 14

Face showing some metallic color. . . . . . . . . . . . . . . . 17

14. Face brownish-yellow, a gray spot on each side below.... signiferus Coq.

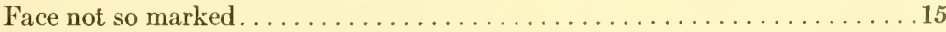

15. Front coxæ with black bristles on the front side besides those at

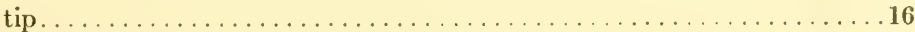

Front coxæ with no black bristles except at tip...... o algens Wheeler.

16. Wings with the spots distinct enough to see with the naked eye.chrysologus Wlk.

The spots only faintly visible with a lens . ............ pirata Loew.

17. With a black propleural bristle............. o algens Wheeler.

With a pale bristle or stout hair................. phoca sp. nov.

18. Face wholly opaque.............................. 19

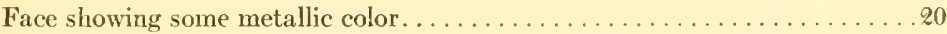

19. Front coxa with a row of black spines in front, longest above, running out apically..........................

Front coxa with a row of spines, longest toward the tip, running out proximally. . . . . . . . . . . . . . . . . . . . pirata Loew.

Front coxa with no spines except at tip ........... extrarius sp. nov.

20. Front coxæ with long and striking spines on the basal part in front............................... innotatus Loew.

Front coxæ with no spines on basal part in front . . . . . . . . . . 21

21. Cheeks projecting downward in a small lobe below the eye

altivagus sp. nov.

Cheeks not forming a lobe below the eye, very narrow .............22

22. Male with a protuberance preceded by a tuft of small spines on

the under side of front femur near tip (fig. 13) ..... amplectens sp. nor.

Male without such structure. . . . . . . . . . . . . . . . . . .

23. Upper part of the face bright blue-green ............ pensus sp. nor.

Upper part of face dull, only a little greenish.........extrarius sp. nov.

\section{DESCRIPTION OF SPECIES.}

(Made with 'Leiss binocular dissecting microscope, 30 diameters.)

Hydrophorus gratiosus sp. nov.

Male. Occiput bluish-green above, with moderate whitish pruinosity; postvertical bristles rather close together, with about four bristles each side, forming a row that joins the postorbitals both ways; the latter extending below the middle of the eye, beard whitish, a few stiff black spines showing just below the neck; front with dense brown pruinosity, not shining; face dirty whitish pruinose, not shining, of medium width; palpi of moderate size, black in ground color, opaque 
like face, with mostly whitish hairs; antenna with rather long first joint, the third wide, all black. Dorsum of thorax moderately shining, with two brown lines in front, in the middle brown, back of the middle a little coppery on both sides; humeral bristles one or two, scutellar one pair; a bunch of long, whitish hairs behind humerus and above the notopleural suture, pleure densely whitisb pruinose, not shining, with conspicuous whitish hairs on propleura and hypopleura, the propleural bristle however black; halteres yellow with brownish base of stalk. Coxæ all with yellowish-white hairs and no black ones even at tip of front coxæ; femora rather opaque, with slight greenish metallic color, tibire and tarsi gradually a little darker; fore femur with numerous short, stiff spines below, arranged very indistinctly in two uneven rows; fore tibil on inner side with a row of short spines, the last two or three at tip becoming erect and slightly longer; the tibia itself is provided with a slight process at tip, turning toward the femur, on which the longest spine stands; fore tarsus fully double the tibia, pulvilli brownish. Wings smoky, costa wholly blackish, an indistinct brown cloud on the hind crossvein and another beyond it on the fourth vein. Abdomen rather shining green, with black hairs above and whitish ones on the sides, the latter rather conspicuous; hypopygium embedded, not very conspicuous. Length, $4 \mathrm{~mm}$; of wing 4.3 .

Female. Length 5 to $6.1 \mathrm{~mm}$.; of wing 5.6 to $6 \mathrm{~mm}$.; otherwise like the male.

Serenteen specimens, both sexes: Moscow, Idaho (type); Pullman, Seattle and Friday Harbor, Wash., dated July 19 and Aug. 2 and 16; Palo Alto and Redwood City, Cal., dated March 1 and April 12, 19 and 25 . Three of the Washington specimens are from Professor Melander, while one from Palo Alto is from the collection of Stanford University.

Another male from Moscow differs in nothing but its minute size, $3.1 \mathrm{~mm}$.

\section{Hydrophorus plumbeus sp. nov.}

Female. Wholly covered with dense plumbeous pruinosity, nowhere showing any metallic color. Occiput with a transverse row of black bristles including the postverticals, which are continuous with the infra-orbitals extending entirely to the mouth; the upper orbitals do not quite connect with this series, so there are half a dozen small black bristles on the upper orbit which are a little isolated from the ones on the orbit below; no black spines under the neck; front plumbeous, yet in oblique view rather blackish, not shining; face very wide, uniformly plumbeous, the palpi concolorous, in the described specimen opened out so that the base of the proboscis shows between-probably not the usual position; antennæ of moderate length, rather slender, the third joint truncated, arista short, its penultimate joint over balf as long as the ultimate, which is hardly tapering at all except at the extreme tip, but ends in a very fine point. Thorax everywhere plumbeous, but with two fine dark lines running back from the front edge in the middle; humeri each with three or four bristles of various sizes; on the mesial side of the humerus a group of bristles, and another behind the humerus and above the notopleural 
suture, where a cluster of whitish hairs occurs in some species (gratiosus); propleura with long white hairs and a bunch of black bristles above the coxa; metapleura also with white hairs; scutellum with a row of erect convergent bristles on the margin on each side, five or six in each; some supernumerary bristles also before the scutellum; halteres yellow. Front coxæ with white hair, long above and shorter below, and a row of small black bristles just above the trochanter; middle and hind coxe with only fine white hair; front femur with irregularly placed spines of all sizes below, indistinctly arranged in a double inner and a single outer row; front tibia stout, gently curved, ending in a slight process with one conspicuous spine, the rest of the inner spines almost imperceptible; the other legs and all the feet somewhat bristly; pulvilli brownish; the legs in every part showing the characteristic plumbeous pruinosity of the species. Wings rather opaque whitish, with a faint brown cloud occupving all the apical two-fifths except a whitish spot in the first posterior cell, and another spot of deeper brown with its center in the basal part of the discal cell and diffusing into the surrounding cells; veins black.

Length, $5.6 \mathrm{~mm}$.; of wing, 5.7.

A single female, Grand Coulee, Wash., Soap Lake, June 29, 1902, from the collection of the Washington State College through Professor Melander.

This species has so many well-marked characters that it is unnecessary to enumerate them. It was collected at a small lake of strongly alkaline water.

\section{Hydrophorus intentus sp. nov. (fig. 4.)}

Male. Everywhere covered with a dense pruinosity, yellowish except on the dorsum of the thorax, and front where it is brown; metallic ground color not visible except very slightly on the abdomen. Occiput with a row of spines extending each way from the postverticals and joining the orbitals rather far down the side; the orbitals extend down nearly to the lower border of the eye; behind them the usual beard is yellowish, and there are black spines under the neck; front sealbrown, face uniformly yellowish pollinose throughout, palpi concolorous in favorable light; antennæ wholly black, first joint moderately long and slender, third wide. Dorsum of thorax rather uniformly brown, humeri lighter; humeral bristles two or three, scutellar about three pairs which are convergent and rather erect, the outer sometimes considerably smaller; propleura with long yellowish hairs and one black bristle; metapleura with fine soft yellow hairs and a few still smaller behind the humerus, above the notopleural suture; halteres yellow. Hairs of the coxæ all pale yellow, long on front ones, which have some black spines on the hind side, next the body, hard to see. Fore femur with two rows of spines underneath, the outer of about seven quite uniform, the inner with four or five larger and an irregular intermixture of smaller ones: front tibia almost straight, with a row of small spines on inner side, the last one larger and erect, standing on a slight elevation; pulvilli brownish. Wings somewhat uniformly brownish, the reins almost black, not lighter at base, an almost imperceptible cloud on the hind crossvein and another 
beyond t on the fourth vein. Abdomen very faintly greenish, cylindrical in middle, the hypupygium small and concealed, not cutting into the fourth sternite at all.

Length, $4.5 \mathrm{~mm}$.; of wing 4.6 .

Female. Differs only in having the abdomen wider in the middle, and showing a rather bright blue-green metallic color on the whole dorsal surface of the abdomen; also in the larger size, $4.9 \mathrm{~mm}$; of wing 5.1 .

Forty-one specimens: Horse Neck Beach (type), Woods Hole, New Bedford, Chelsea, Cohasset, Chatham, all in Massachusetts; Atlantic City, N. J. The Mass. specimens are dated from May 14 to Sept. 8, and were collected by Messrs. Johnson, Hough and Melander. The New Jersey specimens are dated May 6, and were collected by C. IV. Johnson, who informs me that this is the commonest salt marsh species. Professor Melander also reports it extraordinarily abundant in salt marshes at Woods Hole.

I received this from Mr. Johnson under the name of viridiflos Walker, but I do not see how it can be Walker's species. Walker's description is mostly made up of items that would apply to almost any kind of Hydrophorus, or in fact to many other flies; the only character which seems of any diagnostic value is "wingribs and poisers tawny; reins black, tawny at the base." I do not understand the distinction between wingribs and veins, but it seems clear that he was deseribing a species, of which there are several, in which the basal part of the reins is yellow. This character does not apply at all to the species here described. It suggests ostuum to me much more than intentus, as Walker mentions a length of $3 \mathrm{~mm}$.

\section{Hydrophorus cerutias Loew (figs. 1, 5).}

Male. Occiput bright green, with only one pair of postverticals; postorbitals about eight on a side, extending down only about one third of the way to the mouth; beard yellow or whitish, dense; cheeks not visible at all below the eyes; no black bristles under the neck; front yellowish or brownish pruinose; face long, narrow above, wholly white pollinose, palpi concolorous and with rather long pale hairs; antennæ located rather high and pointing almost vertically upward; all the joints elongated, but the third drawn out into a point along the upper edge (see figure); arista short, the basal joint flattened so as to look like the tip of the third antennal joint. Thorax quite bright green or bronze above, especially bright behind; scutellum with only one small decussate pair of bristles, acrostichals and dorsocentrals extremely small, humerals one medium and sometimes one small, notopleural one; a tuft of pale hairs behind the humerus, above the suture; pro- 
pleura with long yellowish or whitish hairs and no black bristle; mesopleura with long hairs of the same color on the lower anterior part; metapleura just in front of halter with a conspicuous tuft, which blends with a similar but shorter one on the posterior upper part of the sternopleura; halteres yellow with brown root; all the coxæ with dense yellow or whitish bair on front side, the front ones with also a lateral tuft near base and no black bristles; front femur not much thickened, on under side with two irregular rows of stiff bristles, and in the rather wide space between the rows numerous irregularly placed short spinules; fore tibia with a row of short spines of increasing length and erectness towards the tip, where the last and largest spine is on a curved point of the tibia; in addition to this row there is on the outer side from it (laterad) another row of larger, more scattered, slanting spines, some ten in number; middle and hind femora slender, rather long, somewhat bowed. Wings slightly infuscated, unspotted, of medium shape, strikingly distinguished by the shortness of the second longitudinal vein, which ends opposite or a little before the hind crossvein (see figure); veins broadly yellow at base. Abdomen bright green, pruinose on sides below, with thin white hairs all over, longest and conspicuous on the sides of the basal joints; hypopygium bulky but short, bent under but not extending much forward. Length, $3.6 \mathrm{~mm}$; of wing, $3.7 \mathrm{~mm}$.

Female. Considerably larger and brighter green than the male; third antennal joint not drawn out into a point as in the male, yet all three of the antemnal joints may be called elongated; the face and the pale hairs of the body surface are yellow, the the latter quite variable in depth of hue. Length, $5.1 \mathrm{~mm}$, of wing the same.

Three males and seven females: Douglas Co., Kans. (Univ. of Kans. Coll.); Brookings, S. D.; Pierre, S. D.; Boulder, Col.

This species has such a wealth of specific characters that a lengthy description seems almost unnecessary. The male has a very remarkable appearance as it goes skating across the surface of a pond, the long antennæ pointing upward like a donkey's ears. I well remember seeing it near Lawrence, Kansas, in June, 1893 , though the males in my collection are not of my own capture, all being from the University of Kansas collection. The females collected by me in South Dakota and Colorado were not recognized at the time. It was Professor Melander's quick eye that first noticed the peculiarity of the second vein, not mentioned by Loew.

\section{Hydrophorus canescens Wheeler (fig. 9).}

Male. Occiput coppery red, with only one pair of postverticals; postorbitals about twelve on a side, ending opposite the ncck; beard white, abundant, mixed under the neck with some black bristles, which seem rather large and numerous; cheek very narrow; front whitish pruinose, only in certain lights with a little coppery reflection; face wholly white pollinose, palpi concolorous with white hairs, antennæ short, of ordinary form. Thorax coppery red or even crimson on most of the dorsum, greenish about the edges, the acrostichals and all the dorsocentrals 
except the posterior pair white; a single pair of scutellars; two humerals, two notopleurals (both large), one posthumeral; propleura with two clusters of long pale hairs, above and below, among the latter some have a rather dark appearance in certain lights, but there is no black bristle; on the upper part of the sternopleura is a cluster of long, loose, woolly, white hairs, very conspicuous; metapleura bare; squama pale yellow with white hairs; halteres yellow, a little brownish at the root. Front coxæe white pollinose and covered in front with long, erect and dense white hairs, no black spines or bristles at tip; front femora thick, not tapering for more than half their length, then with a deep, oblique excavation below cutting out more than half the thickness of the member, beyond which the under side is widened again in a thin longitudinal plate to the tip; the sloping proximal surface of the excavation bears a diagonal series of short black spines; the femur has rather conspicuous white hair on its outer side and on the inner side before the excavation are several much longer white hairs; front tibia strongly bowed out where they oppose the excision of the femur and bare on the flat opposing surface except for a row of minute black spines on the edge which continue, though very small, to the tip; on the underside of the femur near the base are a few short spines in a row; middle coxa with long, erect white hairs on outer part of the front side; middle and hind femora long, slender and somewhat bowed; hind trochanter below with a bunch of black spines which unite to form a tapering, sharp, thornlike process, very striking; middle tibia and tarsus shortened, not much longer than the femur, last tarsal joint flattened and enlarged, black. Wings rather wide with veins yellow at base to a variable extent, unspotted, evenly and moderately infuscated in color; first posterior cell narrowed at end, not much more than half as wide as the length of the posterior crossvein; alula with a row of long, white hairs. Abdomen coppery above, more or less obscured with white pruinosity; all the hairs of the abdomen are whitish and of unusual length, those on the sides near base quite woolly and very striking; fourth sternite projecting $\mathrm{V}$-shaped; hypopygium moderately prominent but not uniformly so. Length, $4.8 \mathrm{~mm}$; of wing, $5 . \mathrm{mm}$.

Female. Color of face from pale yellowish to brownish; front femur gently tapering, not notched, below with an irregular double row of small spines; front tibia with a row of minute spines on inner side which does not extend to the tip. Length, $5.3 \mathrm{~mm}$; of wing, $5.2 \mathrm{~mm}$.

Seven males and two females: Lawrence, Kans., June, 1893; Brookings, S. D.; and Green River, Wyo., Sept. 1, 1896. I remember collecting the specimens at the edge of the river at Lawrence, and $I$ at once noticed the peculiar front legs of the male. The Green River specimens were taken on an occasion when I had to wait between trains all day at the town, but I do not remember the species. My description does not sufficiently bring out the characteristic pale yellowish soft dull coloring of the whole fly, which suggested the specific name. Only the coppery dorsum and greenish abdomen are moderately bright. The type locality was forty miles north of Lusk, Wyoming. 


\section{Hydrophorus agalma Wheeler (fig. 12).}

Male. Occiput rather coppery green, with one pair of postverticals; postorbitals about a dozen, descending about a third of the eye-height; beard white, abundant and long, no black bristles under the neck; the eye meets the mouth, so there is no cheek; front opaque whitish in side view, but coppery with light from behind; face wholly white pollinose, palpi of same color, with white hairs; antennæ small, of ordinary form. Thorax with strong coppery reflection on the disk, mostly outside the dorsocentrals, a dark line in front on each side of the acrostichals. The acrostichals and dorsocentrals are very small in front, but black; hindmost ones very large; scutellar two pairs, large; humeral two, small; notopleural one; pleuræ densely whitish pollinose; propleura with two tufts of long white hairs, one above the other, but no black bristle; sternopleura on the upper part with some seattering very long white hairs; pleuræ otherwise bare; metapleura just in front of the halter with a peculiar protuberance, almost hemispherical; halter yellow with brownish root. Front coxæ whitish pollinose, with abundant long white hairs in front and no black spines; front femur tapering, below with a row of short, blunt spines extending nearly to the middle, about eight in number; front tibia rather straight, with a row of slanting black spines on the front (outer) side, and on the inner a very close row of minute black spinules, rather erect, ending at the tip with two larger small spines; the tibia has on the outer side two or three regular rows of pale hairs; middle femur with a row of long white hairs or bristles on the lower side; the middle tibia and tarsus are rather short, and the last joint of the latter is flattened and black; middle and hind legs provided with an unusual amount of fine white hair. Wings unspotted, rather broad, slightly infuscated, the veins broadly yellow at base, alula with a conspicuous fringe of white hairs, first posterior cell considerably narrowed at tip. Abdomen with a dull coppery reflection, the hairs all white and very long on the sides near the base. Hypopygium bulky, but mostly concealed. Lengtli, $5.2 \mathrm{~mm}$.; of wing, $4.9 \mathrm{~mm}$.

Female. The pollen of the body is a little yellowish, and the face is decidedly yellow; the front femur below has an irregular double row of spines, 25 or 30 in all; all the spines of the front tibia are larger; no white bristles under the middle femur; middle tarsus normal; sides of abdomen with shorter hairs. Length, $5 \mathrm{~mm}$; of wing, $5.3 \mathrm{~mm}$.

Three males and two females, collected by me at Battle Creek, Mich., in the summer of 1897; Professor Wheeler's types were out of this lot.

The species has many interesting points of resemblance with canescens, but also has easily discerned differences.

\section{Hydrophorus eldoradensis Wheeler.}

\section{Hydrophorus aestuum Loew.}

Male. The whole insect covered with whitish pruinosity, less dense on the dorsum, which shows a little metallic color. Occiput with only two postverticals, and only six to nine postorbitals on a side, extending only about a third of the way to the mouth; beard white, no black bristles under the neck; cheeks hanging down as a vertical flap below the eyes, which is short antero-posteriorly; face very wide, 
wholly white pollinose, antennæ of usual form, small, first joint not elongated. Thorax with two small cupreous stripes in front, enclosing the acrostichals and extending to the middle; outside the dorsocentrals is a wider cupreous stripe on each side abbreviated at both ends. These stripes are often but little visible. Scutellars two pairs, humerals two, notopleural one and sometimes another much smaller; squama pale yellow with white hairs; halteres pure yellow with a dark root; propleura with white hairs and one black bristle; a few microscopic white hairs on sternopleura; front coxæ with white hairs in front and few minute black spines at tip; fore femur on the under side with one row of spines of irregular size, larger along the middle. These are on the inner side of the folded tibia, but at the tip is a single spine that comes on the outer side. There is a little variation in these femoral bristles, and in one of Wheeler's cotypes of eldoradensis, a male, from Magdalena Mts., N. M., I find by removing the tibia that the femoral bristles consist of a series near the base of about five minute ones bent laterad and three larger ones near the middle, standing straight down; these all form a row as far as their insertion is concerned. Wheeler's description of two rows must refer to the female. Tibia with a row of setules on the inner side, progressively longer and more ercet toward the tip, the last one still longer and standing on a sharp inwardly curved point of the tibia. Middle and hind femora simple, slender but not greatly elongated, both a little bowed. Wings hyaline, unspotted, of medium size, the veins broadly yellow at base; this yellow color varies greatly in different specimens, but generally the costa is yellow to a point about halfway between the tips of the first and second veins. Third and fourth veins quite strongly convergent at tips.

Abdomen more or less greenish, rather broad and short, covered with white hairs; the male appendages are so small and retracted that it is often difficult to determine the sex of the specimen. Length, $3.2 \mathrm{~mm}$.; of wing, $4.5 \mathrm{~mm}$.

Female. Postorbitals about a dozen on a sirle; bristles of the lower side of front femur in two rows, which are a little irregular near the middle.; Length, $4.5 \mathrm{~mm}$.; of wing, $5.3 \mathrm{~mm}$.

Thirty specimens, both sexes: Magdalena Mts., N. M., Aug1894, W. A. Snow; Las Cruces, N. M., Aug. 23; 40 miles north of Lusk, Wyo., July, 1895; Palo Alto, Cal., Aug. 6, 1894 (all the seven preceding specimens are cotypes of Professor Wheeler's eldoradensis, from Professor Melander's collection); Texas, October 18, 1899; Jacksonville, Tex., Oct. 20, 1895; Tifton, Ga., Sept. 24, 1896; Biscayne Bay, Fla. (Mrs. Slosson); De Funiak Springs, Fla., Mar. 1, 1900; Brookings, S. D., one pair copulating on surface of water, Apr. 10, 1900; Moscow, Ida.; Pacific Grove, Cal., on seepage of sand dunes near sea beach, May 6, 1906; Palo Alto, Cal., Oct. 7, 1905; Redwood City, Cal., Apr. 25, 1906; California (Coquillett).

The type locality of aestuum was Newport, R. I., which with Johnson's recently published New Jersey records, nicely rounds 
out the localities so that they cover practically the entire United States. This is undoubtedly the most wide-spread species that we have; it is also considerably variable in several of its characters notably the amount of white pruinosity it bears. A specimen sometimes looks quite metallic on one side, showing that a slight amount of rubbing easily takes off the "dull finish" provided by nature. The coppery stripes on the thoracic dorsum are sometimes only green, sometimes almost obsolete. In general, it may be described as a small species with considerable whitish pruinosity, opaque face, white hairs all over except the distal portion of the legs, and with hyaline wings, unspotted, the veins yellow at base. Loew failed to mention the paleness of the wingreins, which misled Professor Wheeler. Mr. Brues compared some of my material with Loew's types of cestuum at the museum of Comparative Zoölogy, and could find no material differences.

Osten Sacken, in his Western Diptera, p. 320, probably had this species,- - the second undetermined species mentioned.

\section{Hydrophorus philombrius Wheeler (fig. 14).}

Male. Occiput moderately shining green, the postvertical bristles only a single pair, vertex considerably excavated on each side of the ocelli, which are on a tubercle; front shining green, concave, wide above; face concave above the middle, smooth and brilliantly shining, the metallic color usually continuing down over the suture, which is elevated on a protuberance; there is considerable variation in the brilliance of the color, even on the upper face, but it is always perceptible; below the protuberance sloping backward to the palpi, which are darker with brownish hairs. The cheek a thin sharp plate, yellowish sericeous, standing straight down on each side of the mouth; the face widens rapidly from a point just below the antennæ; the black postorbital bristles extend down behind the eye only about to the middle; beard whitish and dense, making it impossible to tell certainly whether there are any black bristles under the neck, though I think there are; antennæ short, the first and second joints of about equal length. Thorax above striped with green and coppery, the former color occurring along the rows of bristles; only a single row of acrostichals, beginning rather far back; dorsocentrals small except the hindmost one; scutellars four, strong; two humerals; the hind notopleural small; pleura rather dull with gray pruinosity, almost destitute of fine hairs; propleura however with whitish hairs, longest just below the single black bristle; front coxa with a somewhat sericeous whitish pruinosity, and fine white hairs, also at the upper outer corner two or three small black bristles and five or six on the outer side of the front near the tip; femur thick at base, rather bare, below with two rows of bristles at base, the outer of only about four rapidly increasing ones and the inner of five or six of rather uniform size, and beyond the latter a few extremely short little stubs showing above the surface; front tibiæ strongly curved inward at tip. 
and bearing on the inner side a row of little spines, quite erect all the way, the terminal one not large; the other femora and tibiae quite shining; halteres yellow to dark yellow, the knob not with a darker spot, the stem dark at base. Wings almost hyaline, without spots, the veins yellow at base as far as the middle of the basal cells and the first vein farther, the costa however only pale halfway to the humeral. Abdomen greenish, short, with whitish hairs on the sides and below, fourth sternite divided, behind it a pair of blackish protruding flaps.

Length, $3.9 \mathrm{~mm}$.; of wing, 4.2.

Female. Face generally not bright below, yet distinctly green in the concave upper portion; front coxæ with the black spines quite small; dorsum of thorax more opaque, hardly shining.

Length, $4.8 \mathrm{~mm}$; of wing, 5.5 .

Thirty-two specimens: Battle Creek, Mich.; McHenry, Ill. Lawrence, Kans.; Brookings and Pierre, S. D.; Austin, Tex.; Moscow and Craig's Mt. in Idaho; Palo Alto and Pacific Grove, Cal.; Longmire's Springs and Coulee City, Wash. The last and the material from Texas and Illinois are from Professor Melander. Dates: Austin, Texas, Oct. 29 and Dec. 25; Palo Alto, Apr. 12; Pacific Grove, May 6; Brookings, S. D., Apr. 25; Longmire's, Aug. 2; Coulee City, June 25 and July 13. The species evidently has a long season as well as a wide distribution. The dated specimens from Brookings have some personal interest, as I collected them in the spring of 1890 , just after I had decided, under the advice of Professor A. J. Cook, to take up the Diptera as a specialty.

Hydrophorus breviseta Thomson (figs. 10, 11).

Male. Occiput green, with a bluish pruinosity, postvertical bristles only two; orbitals extending about two thirds of the way down behind the eye, beard yellow, numerous stiff spines below the neck; front opaque brownish; face green above, below with some brown pollen; the eyes reach as far down as the lower edge of the face, and the cheek is in the form of a very narrow vertical plate; palpi dark brown with hairs of the same color; antennæ small and very short. Dorsum of thorax rather brown, not shining, with a row of small lighter spots on each side, where they intervene between the dorsocentrals; four large scutellars; pleuræ rather green in the middle, whitish pruinose below; propleura with conspicuous yellowish hairs and one black bristle; mesosternum with thin, pale hairs; halteres rather deep yellow. Front coxæ with scattered pale hairs and at tip a few small black spines; front femur thick at base, on its lower side at extreme base about five little black spines with some whitish hairs, then about the middle a row begins of very long bristles which decrease rapidly; front tibia with a swelling on the inner side, largest just beyond the middle, followed by a deep excavation, beyond which to 
the tip the outline again rises; the outer side of the tibia is also crooked and convex over the excavation, and along almost its whole length has distinct, long hairs; the inner side is provided with a row of short, erect spines, beginning before the middle, interrupted at the excavation, and continuing again in only three or four spines to a point halfway between the latter and the tip, so that there are no spines near the tip at all, but only delicate pale hairs on the inner side, tarsi simple, with brownish rather large pulvilli. Middle femora slender, a little bowed; middle tibia with a few extra bristles on the inner side near the tip; tarsus a little shorter than the tibia, its first joint bristly on the inner and hind side, the last two joints black, flattened, and with a dense tuft of stout black hairs on the hind side of each; pulvilli and empodium rather large, brownish. Hind legs of ordinary form. Wings slender, but faintly infuscated, a rather distinct spot on the hind crossvein but none beyond, veins black, humeral and the large stem behind it somewhat paler; abdomen moderately shining above, rather long, strongly concave below; underneath the fourth segment are two flaps with yellow hair; terminal organs large, folded under.

Length, $3.9 \mathrm{~mm}$; ; of wing 4.8 .

Female. Instead of the long bristles on under side of front femur, there are only a row of short, stiff ones; the front tibia is provided with a simple row of small slanting spines on the inner side, not interrupted and extending to the tip.

Length, $4.3 \mathrm{~mm}$.; of wing, 4.9 .

Four males and four females: three males and three females were collected at Friday Harbor, Wash., July 17, 1905; two males and two females, same locality, collected by Professor Melander on July 7, 1909; one female, Kanaka Bay, San Juan Island, Wash., (four miles from Friday Harbor) May 31, 1906; and one male sent me many years ago by Mr. Coquillett, Alameda, Cal., which is presumably just about the type locality.

\section{Hydrophorus sodalis Wheeler.}

Male. Occiput green, moderately shining, with only the usual two postverticals; front rather obscure green; face wide, shining green close to the antennæ, but with a white pollen covering the lower two-thirds; palpi brown; postorbitals scarcely coming down to the level of the middle of the eye-just ten on a side in the described specimen,- - beard dense and white, no black spines under the neck; cheek forming a narrow vertical plate, densely white pollinose; antennæ small, first joint short. Thorax and scutellum greenish bronze, rather shining; acrostichals in a row of five, dorsocentrals sixin each row, the fifth longest, but all rather long, scutellar four, strong; pleuræ with dense white dust, especially below: propleura with long white hairs and one black bristle, no other hairs on pleura except a few microscopic white ones on the upper hind part of sternopleura; halteres dark yellow; wings almost pure hyaline, unspotted, third and fourth veins rather widely separated at tip. Color of veins black, scarcely lighter at base. Front coxæ with short white hairs, usually a few minute black setules at apex, and occasionally a 
small black hair near base; front femora thick at base, below with white hairs on outer side and a row of about four stiff spines near base, on the inner side below with numerous black spines in one row, "five to seven spines in the broader basal portion of the femur are considerably longer than the other spines, which are inserted in two or three irregular rows." Inner side of the front tibia with a regular row of stiff spines, running up on a slight process of the tibia at its distal end. Middle and hind legs simple, tarsi blackish with yellowish pulvilli. Abdomen short and compressed, bronze-green, the hypopygium retracted. Length, $2.9 \mathrm{~mm}$; of wing 4 .

Female. Beard and hair of front coxæ more yellowish; the postorbitals come down two-thirds the height of the eye-thirteen in number in the specimen. Wings a little more infuscated. Length, $2.7 \mathrm{~mm}$; of wing, 4.7 .

The description is drawn from eight cotypes in Professor Melander's collection, Hunter's Creek, Wyo., Sept. 11, 1895, Lusk, Wyo., Aug. 26, 1895, and Black Rock Creek, Wyo., Sept. 13, 1895. I also have eight females, Marshall Pass, Colo., 10,856 ft., July 28, 1908 .

Hydrophorus magdalena Wheeler (fig. 6).

Male. Occiput bronze-green, with some brownish dust and only two postvertical bristles; front opaque brown; face rather wide, slightly dusted allover, yet with the green metallic ground color showing through distinctly on the upper half, where the dust is brown; on the lower half the pollen is yellowish white; palpi dark brown pollinose; antennæ rather small, first joint a little stout at apex; cheek narrow, dependent; postorbital bristles about twelve, descending a little below the middle of the eye; beard yellowish, a few black spines under the neck. Thorax golden green, heavily overlaid toward the front with brownish dust, which extends down on the pleuræe and becomes gradually paler; six or seven dorsocentrals, two humerals, four large scutellars; propleura with long yellowish hair and one black bristle; a few microscopic scattered white hairs on the upper end of the sternopleura; halteres yellow; wings moderately broad, veins yellowish at base, the costa becoming black at the tip of the first vein or beyond it. Legs rather bright golden green; front coxæ with rather long whitish hairs and at tip a few small black setæ; front feruora with white hairs and a short row of spines on the outer side below at base; on the inner side below a row of spines extending abont all the length; tibia on inner side with a row of slanting spines, the apex of the tibia not enlarged toward the femur; all the tarsi blackish, with large, divergent claws and brownish pulvilli. Abdomen quite bright green, with long, almost woolly white hair along the sides extending to the tip in diminishing length; hypopygium concealed, the two flaps that project behind the lower part with rather long and dense white hair; fourth segment projecting V-shape below. Length, $3.5 \mathrm{~mm}$; of wing, 4.5

The female differs hardly at all from the male. Length, $4.6 \mathrm{~mm}$; of wing, 5.7. 
Twenty-five specimens: Mt. Rainier, Wash., above Longmire's Springs, Aug. 3, 1905, and Marshall Pass, Colo., July 28, 1908. Compared with cotypes loaned me by the American Museum of Natural History.

I was in doubt about the identification until I had examined the cotypes, as in my material the costa is not yellow so far from the base as in Wheeler's.

\section{Hydrophorus signiferus Coquillett.}

(Copy of original description.)

Female. Upper part of the occiput, front and face opaque, densely brownishyellow pruinose, a small gray spot below each of the facial tubercles; palpi brownishyellow pruinose in the center, the edges gray; proboscis and antennæ black, third joint of the latter subquadrate, slightly broader than long; a notch at insertion of the arista and another opposite it on the lower side of the joint; penultimate joint of arista one-half as long as the last joint; bristles of occiput black, intermixed with a few pale yellow hairs. Thorax blackish, the margins and upper part of the pleura opaque, densely brownish-yellow pruinose (center of the dorsum may have been abraded in the single specimen before me), remainder of pleura white pruinose; scutellum opaque, densely brownish-yellow pruinose, bearing four bristles. Abdomen shining bronze green, the lateral margins and venter white pruinose. Coxæ and trochanters deusely whitish pruinose, femora and tibiæ shining, bronze green, the tarsi black; front femora bearing a few short spines on the basal third of the under side. Wings grayish-hyaline, veins bordered with pale brown, a dark brown spot on the hind crossvein and another near the middle of the last section of the fourth vein; third vein toward its apex strongly curving toward the fourth; hairs of lower calypters pale yellow. Halteres yellowish, the knobs brown Length, 6 $\mathrm{mm}$.

Type.-No. 4052, U. S. N. M.

Bering Island, July-August, 1897. A single specimen collected by Mr. Barrett-Hamilton.

Hydrophorus algens Wheeler.

Face rather wide in both sexes, only moderately narrowed above, bulging and then receding below, with brownish-yellow dust, which is denser in the male, allowing nothing of the ground-color to be seen; in the female however the metallic blue-green color shows through, but is not very bright. Palpi with brown dust and mostly yellow hairs; front opaque brown; postorbital black bristles in a rather dense row, beard yellow; postvertical bristles only one pair. Thorax with thin seal-brown pruinosity extending down to the middle of the pleuræ, where it changes suddenly (viewed from in front) into glaucous; dorsocentral and acrostichal bristles erect, long and slender, about $10 \mathrm{dc}$ in a row. A lighter color in spots between these bristles (in the row) gives the effect of three paler lines on the dorsum; four strong scutellars; propleural one, among yellow hairs; halteres dark brown, stem yellow. 
Abdomen concolorous with thorax, glaucous on the sides to a little above the suture; hairs black above, pale on the glaucous portion; male appendages much retracted in drying, as usual. Front coxæ with abundant yellow hairs on fore side and no black spines at all; front femora only moderately robust, with yellow hair on inner side, long toward the apex in male; underneath at base outside the flexed tibia with four (male) to seven (female) smallish spines of increasing length distally; fore tibiæ almost straight, with a row of slender short spines on flexor side, stronger distally. Wings indistinctly brownish with the two dots plainly visible to the naked eye; none of the veins yellow. Length of male, $4 \mathrm{~mm}$.; of female, $3.9 \mathrm{~mm}$.

Redescribed from cotypes, one male and one female, collected by Wheeler at Two-Gwo-Tee-e Pass, Wyo., Sept. 12, 1895. The specimens were loaned to me for study by the American Museum of Natural history.

I have seen no more material in this species. It differs from chrysologus in having fewer spines on the under side of the front femur. Chrysologus is mostly eastern, but I have one male from Boulder, Colo.

\section{Hydrophorus chrysologus Walker.}

Male. Occiput, front, face and palpi wholly seal-brown pollinose, opaque; postorbitals one pair, postverticals about twelve in number on a side, extending down more than halfway behind the eyc, beard deep yellow, abundant; cheek very narrow; palpi with brown hairs; antennæ rather small, with no unusual features. Thorax and abdomen deep brown above, somewhat shining; this color extends down on the pleura a short distance, and correspondingly on the abdomen, below glaucous. In one of the two males the abdomen is distinctly more greenish. Scutellar bristles two pairs, humeral two, notopleural two; dorsocentrals much smaller than in pirata, acrostichals minute; propleura with stout yellow hairs and one black bristle; remainder of pleura bare except a few microscopic hairs on the mesopleura; squama brown with yellow hairs; halteres brown, the middle of the stem yellowish. Front coxæ yellowish pollinose on the inner half of the front side, the rest somewhat glaucous, a row of small black spines running up the front outside the middle line; these spines are scattering and irregular; front femora not much thickened, below with two irregular rows of spines of uneven size and between the rows some minute setules; tibia straight, with a row of short rather inclined spines on the flexor side as usual, not ending with a longer spine; the other femora not especially slender nor elongated for this genus. Wings narrow, with black veins, almost hyaline with distinct spot on hind crossvein and another beyond it on the middle of the last segment of the fourth vein; these two spots can be seen with the naked eye against a white background. Fourth segment of the abdomen with a $\mathrm{V}$-shaped projection below, more conspicuous in a shriveled specimen than in a normal one; the latter has two long lamellæ hanging down near apex, which are folded in in the other specimen, so the hypopygium does not look like the same structure in the two specimens. Length, $3 \mathrm{~mm}$.; of wing, $3.5 \mathrm{~mm}$. 
Female. Very like the male and about the same size in some specimens; some unshriveled ones a little longer.

Seven males and fifteen females: Crawford's, Franconia and Mt. Washington, N. H. (Mrs. Slosson); New Bedford, Mass., April 20, 1896 (Hough); Provincetown and Eastham, Mass., (C. W. Johnson); Montreal, Quebec, Sept. 8, 1901 (G. Beaulieu); Battle Creek, Mich.; Boulder, Colo.

I at first identified this with glaber Walker, but according to the description that species has yellow halteres. The references in my catalogue under glaber, mentioning its occurrence in Alaska and New Hampshire, are probably this species.

\section{Hydrophorus phoca sp. nov. (fig. \&).}

Male. A small species with brown dorsum and spotted wings. Occiput greenish with only the ustial postvertical bristles; front and vertex sealbrown, not shining; face of moderate width, with brown pollen, which is so thin on the upper half that the green ground color shows through very plainly; this part of the face has deep longitudinal corrugations; palpi dark brown; antennæ wholly black, the first joint short, hardly longer than the second; third joint also small; infra-orbital bristles extending down almost to the lower border of the eye, beard yellow, no black bristles below the neck. Thoracic dorsum brown above with two faint rows of lighter spots that intervene between the bristles of the dorsocentral rows; the posterior part of the thorax is damaged by the pin in the described specimen; scutellum rather bright green, with four large bristles; the bristles of the sides of the thoracic disk are much larger than those of the central part; two small humeral bristles; no hairs behind the humerus; propleura with yellow hairs only on its lower part, and above them a rather strong yellowish-brown bristle; no perceptible hypopleural hairs; both halteres missing in the described specimen. Front coxæ with yellow hairs, long above, and only two or three small black spines at tip; front femur thick at base, below with yellow hairs near base and in the same region a short row of only four or five black spines; the front tibia not much curved, almost straight, seemingly with only minute setulæ on the inner side, but in the specimen it is impossible to see the structures here very well; middle and hind femora long and slender. Wings slightly brownish, with a distinct brown spot on the hind crossvein and another on the fourth vein a little beyond, both distinctly visible to the naked eye; all the veins black to the base. Abdomen small and short, greenish above, pruinose on the sides and below, bearing pale hairs below and longer ones on the sides of the first segment above; the fourth sternite has a ridge in the middle, which is split from behind forward.

Length, $3.1 \mathrm{~mm}$; of wing, 4.4 .

One male, collected by the late Rev. Mr. Livingston, at Corfield, Vancouver Island, B. C., dated 8-7-96; from Professsr Melander. 


\section{Hydrophorus parvus Loew. (fig. 3.)}

Male. Minute brown species with wholly dark brown halteres. Occiput brown, one pair of postverticals, postorbitals twelve, extending about halfway down the eye; opposite the ocellar tubercle on the orbit an unusually long proclinate and convergent pair of bristles; beard white and rather thin, cheek narrow; no black bristles under the neck; front brown; face narrow above, yellow to brown, entirely opaque, palpi blackish; antennæ of medium size, not elongated, still the third joint protuberant at tip in the middle. Thorax sealbrown above the notopleural suture and glaucous below; two pairs of scutellars, one humeral and one or two hairs; one posthumeral, two notopleural, both large; seven large dorsocentrals in each row; acrostichals small; all these thoracic bristles are comparatively large; propleura with only a few small white hairs and one black bristle; mesopleura with only a few microscopic white hairs, the pleura otherwise bare; halteres wholly dark brown; squama brown, with yellowish hairs. Front coxa white pruinose, with very few white hairs, but a row of black bristles down the front side, largest at proximal end, tapering off into a few white hairs near tip; there are also a few black spines across the tip. All the legs below the coxæ dark green, he tarsi blackish; front femora below with about three stout spines near base, on the inner side with a row of small spines most of the length; front tibia on the inner side with a row of inclined spines, longer distally, but not ending in a prominent spine; middle and hind femora slender, a little bowed. Wing narrow, subhyaline, veins black, first posterior cell not narrowed, last section of fourth vein straight; last section of fifth vein as long as the posterior crossvein. Length, $2.6 \mathrm{~mm}$; of wing, $3.5 \mathrm{~mm}$.

Female. Face brown, narrow; resembling the male very much in all respects. Length, $2.8 \mathrm{~mm}$; of wing, $3.6 \mathrm{~mm}$.

Three males and two females: New Bedford, Mass. (Hough); Hampton, N. H., April 17 and 22 and May 5, 1904 (from C. W. Johnson, collected by S. A. Shaw); Somerset, Mass., Dec. 31, 1904 (from C. W. Johnson, col. by N. S. Easton). The type locality was Illinois.

Hydrophorus pirata Loew.

Male. Occiput brownish pruinose, with one pair of postverticals; postorbitals about sixteen on a side, descending nearly to the lower edge of the eye; beard rather light yellow; cheek rather narrow; front and face opaque brown, palpi dark brown with black hairs; antennæ of ordinary structure, but the first joint a little elongated. Dorsum of thorax and abdomen sealbrown, this color extending a little below the notopleural suture and correspondingly on the abdomen, the side of the body below being densely white pruinose with a slight glaucous tinge; scutellar bristles two pairs, humeral two, notopleural two, the dorsocentrals much smaller, yet not so small as in some species, about 11 in number, the next to the last largest; propleura with a few delicate yellowish hairs above, some coarser ones below that seem almost brown in certain lights, and one large black bristle; pleuræ with no other hairs except a few microscopic whitish ones on mesopleura; squama brown with yellow hairs; halteres with brownish stem and very dark, almost black, knob. 
Front coxæ with a row of about sixteen black bristles on front side, more slender and delicate above, and with rather dense hairs on the mesial side of the row; femora and tibiæ somewhat shining green, the former only moderately thickened at base, below with a scattering row about ten short spines on the inner side, extending the whole length, and on the outer side six or seven forming a row on the basal half; tibia with a row of spines on the inner side, not erect nor enlarged at tip, and the tibia is not bent toward the femur at apex. The middle and hind femora bright green, rather slender. Wings a little infuscated, with black veins, a slight cloud on the hind crossvein, not very apparent but constant. Abdomen showing a little green above, the sides of the two basal segments with rather woolly brown hair; hypopygium mostly concealed. Length, $4 \mathrm{~mm}$.; of wing, $4.9 \mathrm{~mm}$.

Female. All that $\mathrm{I}$ have seem to have the abdomen shortened in drying, otherwise not differing from the male. Length $3.6 \mathrm{~mm}$; of wing, $5.1 \mathrm{~mm}$.

Fourteen specimens both sexes: Franconia and Crawford's, New Hampshire, (Mrs. Slosson); New Haven, Conn., Oct. 21, 1903 (C. W. Johnson, collected by H. L. Viereck); Danvers, Mass., Sept. 23 (C. W. Johnson); Montreal, Que., Sept. 1, 1901 (G. Beaulieu).

In some specimens there is a distinct metallic reflection on the upper half of the face when the light comes from straight in front or a little below.

\section{Hydrophorus extrarius sp. nov.}

Female. Occiput moderately shining green, with one pair of postverticals; postorbitals about fifteen, descending hardly to the middle of the eye; cheek very narrow, beard white; no black bristles below the neck; front brownish pollinose, in some lights dark greenish; face rather narrow for the sex, somewhat pollinose all over, yet on the upper, concave part a dull green shows through the brown dust; lower convex part of the face with dense brown dust in the middle, and whitish on the sides; palpi gray, with mixed whitish and black hairs; antennæ of plain structure, a little longer than in some species. Thorax rather seal brown above, brighter green behind; at the notopleural suture this changes to glaucous; scutellar bristles two pairs, notopleural two, humeral two rather small, dorsocentrals fairly well developed but slender, acrostichals except at extreme front of the same size as the last. Propleura with white hairs and one black bristle; sternopleura with only a few microscopic pale hairs; squama yellow with whitish hair; halteres yellow, with a large brown spot on the knob. Frout coxæ glaucous, with dense, short white hair in front and no black spines except two or three short ones at the tip; front femur not very much enlarged, below with a short row of five or six spines on the outer side at base and another short row on the inner side toward the tip (in one specimen a few small scattering spines continue this inner row toward the base more than in the other one); front tibia straight, with the usual row of small spines on the inner side quite slanting, not enlarged toward tip; middle and hind femora rather slender and a little bowed; wings almost hyaline, unspotted, veins 
black at base, third and fourth veins not appreciably convergent at tip. Abdomen rather bright bluish green, glaucous underneath, hairs of the bright part black, of the glaucons part white. Length, $3.8 \mathrm{~mm}$.; of wing, $5.1 \mathrm{~mm}$.

Two females: Brookings, S. D. (type) and St. John's, Quebec, Aug. 8, 1901, the latter collected by G. Beaulieu, his number 46.

I hesitated a long time before describing this species. After long consideration I satisfied myself that it is recognizably distinct, even in the female sex alone, so for the sake of completeness I give it a name. Its relationships are with pirata perhaps more than any other species, but the absence of procoxal spines and the different color of the face, with other characters, are sufficient to distinguish it.

\section{Hydrophorus innotatus Loew.}

Male. Occiput green, with brown dust, not bright, only two postverticals; front opaque brown; face bright green above with only a little brown pollen, changing to white above the suture and densely covering the lower half; palpi brown; cheeks forming narrow flaps; the black postorbital hairs about 18 in number, descending two-thirds of the way to lower edge of the eye; beard yellow, dense, mixed under the neck with a few black spines; antennæ short and small, first joint hardly larger than second. Dorsum of thorax and abdomen rather uniform sealbrown; seutellars two pairs, acrostichals in a rather dense row, dorsocentrals slender in front, the posthumeral strong; pleuræ glaucous except irregularly along the upper part, where they are brown like the dorsum; propleura with yellowish hairs and one large black bristle; halteres with brownish knob; wings hyaline, veins black. Front coxæ glancous, with very small white laairs and a conspicuous row of black bristles, about seven in number, longest at the base, placed rather on the outer side of the member; these bristles do not quite reach to the apex, but after an interruption there are more placed somew hat transversely across the tip; front femur below with a row of short but stout spines on the inner side, smallerand irregularly placed near the base, and on the outer side a row consisting of three or four rather large spines at base and beyond them as many more notably large, long ones, standing far apart, the last a little beyond the middle; front tibiæ with a very regular row of small inclined spines, not larger at tip, where the tibia curves slightly toward the femmr; the other legs of plain structure. Abdomen short, brown down on the sides almost as far as the suture, glaucous underneath; hypopygium small, fourth sternite projecting $\mathrm{V}$-sliaped, this and the lobes of flaps behind bordered with whitish hairs; sides of abdomen with yellowish hairs near base.

Length, $3.7 \mathrm{~mm}$.; of wing, $5.2 \mathrm{~mm}$; the latter indicates that the specimen is abnormally shortened in drying, or else has naturally a very short abdomen.

The female has a wider face, and the dust is wholly brown on the lower part, except just below the suture on each side, where it shows a tendency to a white spot as in signiferus. This is largely a matter of the direction of the light. Halteres distinctly brown on the knob, rather more so than some males. Length, $4.1 \mathrm{~mm}$.; of wing, $5.2 \mathrm{~mm}$. 
Twelve specimens, both sexes: Beaver Creek, Newport, Oregon, Aug. 13, 1902; Keyport, Wash., Aug. 7, 1905; near Seattle, no date; Bellingham, Wash., July 29; Lyndon, Wash,. July 29, 1908. The last two lots mentioned are from Professor Melander, and the preceding one from Prof. O. B. Johnson. The type locality of the species was Sitka. Loew's description is easily recognizable and there can be no doubt of the identification.

\section{Hydrophorus altivagus sp. nov.}

Male. Occiput bright metallic green with faint brownish pruinosity; postverticai bristles one pair; postorbitals about fourteen on a side, extending a little over halfway down the eye; beard yellow, no black bristles below the neck; cheeks wide; front brownish pollinose, not much shining; face bright green on the upper fourth, the rest white pollinose; palpi strongly contrasting dark brown, with blaek hair; antennæ short, of ordinary form. Dorsum of thorax rather dark bronze-green, moderately shining; upper part of pleura concolorous with the dorsum for a narrow space; scutellar bristles two pairs, humeral two, notopleural two; dorsocentrals comparatively large for the genus, the penultimate one almost as large as the scutellars; propleura with long, delicate yellow hairs and one strong black bristle; mesopleura with a few microscopic pale hairs; squama yellow with yellow hair; halteres almost black, the stem yellow in the middle. The pruinosity of the pleura is almost white. Front coxa with abundant yellowish bairs on the anterior side; five or six black spines at tip and a row of black spines, four in the described specimen, running up the outer front edge from the tip about halfway to the base; front femur moderately thickened, on the inner side below with seven stubby spines forming an irregular row the entire length, on the outer side below there appear to be only two or three short spines at base; front tibia straight, with the usual row of small spines on the inner side; they are not erect, and are very uniform; middle and hind femora shining blue-green, not very slender. Wings large and rather broad, subhyaline, veins black, unspotted. Abdomen rather bright bronze-green above and on the sides almost to the suture, the rest whitish pruinose; hypopygium more concealed than usual. Length, $4.7 \mathrm{~mm}$; of wing, $5.1 \mathrm{~mm}$.

Female. Face with yellowish-brown dust below, on each side below the suture changing to gray; palpi as in the male, blackish; front coxæ with one spine above the tip or none (this is evidently a variable character); spines on under side of front femur as in the male but somewhat longer. Length, $4.8 \mathrm{~mm}$.; of wing, 5.6 $\mathrm{mm}$.

One male, Marshall Pass, Colo., Alt. 10,856 ft., July 29, 1908; three females, Boulder, Colo., August, 1897.

Hydrophorus amplectens sp. nov. (figs. 8, 13).

Male. Postorbital black bristles about twenty-six in number, extending almost down to the lower corner of the eye, postverticals only two, beard pale yellow, cheeks exceedingly narrow; occiput green, front sealbrown, face rather narrow, 
shining green above, on the lower part with brown dust; palpi dark brown with blackish hairs; antennæ plain, small, first joint not elongated; underneath the neck among the beard are rather numerous black bristles. Dorsim of thorax shining sealbrown, green before the scutellum and around the humeri, the acrostichal and dorsocentral bristles very small and thin and rather numerous; even the hindmost dorsocentral is thin and small; scutellars four; upper part of the pleura quite pure green, lower part glaucous pruinose, few almost imperceptible microscopic hairs on the upper part of the sternopleura; propleura with pale yellow hairs and one black bristle; halteres brown on the outer side of the knob; front coxæ with fine brownish hairs on the front side and small black spines at and above the tip; front femora not much thickened, with a single row of bristles below along the middle, about nine to twelve in number; near the tip below there is a prominence followed by an excision; just back of the prominence is a close row of five stiff and bluntly pointed spines; on the front tibia at the base is a slight lateral prominence about opposite the excision in the femur, surmonnted with minute spines; following this to the apex is the usual row of small, rather erect spines; the effect of the excision and both prominences is evidently to form an organ for holding the female. The other legs of plain structure, except that the last two joints of the middle tarsi are black and somewhat flattened, the fifth joint more so than the fourth. Wings of moderate widtl, subhyaline, the veins black, with almost imperceptible spot on the hind crossvein and anotlier bryond (in one specimen these are considerably stronger). Abdomen bright bluish green, glaucous only below and on the under part of the sides; fourth sternite emarginate behind and the space occupied with a large black organ which seems to end in a thin edge behind, quite different from most species. Length, $4.2 \mathrm{~mm}$; of wing, 4.8 .

Female. The face is much wider, front and middle legs of plain structure. Front femur below with loose brown hairs and toward the tip a small spine or two. One female has the two spots of the wings more developed than the rest, but still faint. Length, $4 \mathrm{~mm}$., of wing, $5.1 \mathrm{~mm}$.

Three males and two females, all taken at Brookings, S. D.; three were captured in early spring of 1890. One male, Battle Creek, Mich., summer of 1897.

The female differs from that of magdalene in having much shorter dorsocentrals, no row of spines under front femur, and a brown spot on knob of halteres. The male differs in the structure of the fore legs and in having a narrower face, as well as in the smaller dorsocentrals.

\section{Hydrophorus pensus sp. nov. (fig. 7).}

Occiput shining green, only one pair of postverticals, the postorbitals about twelve in number, extending down only about one-third the height of the eye; beard white; no black bristles under the neck; cheek below the eye exceedingly narrow; front dark brown, hardly at all greenish; face narrow above, smooth and brilliant blue, below covered with white dust; palpi concolorous, with pale hairs; eyes with 
larger facets just below the antennæ; antennæ of medium size, not quite so short as in some species, arista rather long. Dorsum of thorax sealbrown in front, green behind; four scutellars, two humerals, dorsocentrals of moderate size, the hind ones rather strong; pleuræ wholly white pruinose, bare, propleura with white hairs and one black bristle; squama blackish with pale hairs; halteres yellow with brown spot on knob and brown root. Front coxæ white pruinose and with fine soft hair, at tip sometimes with a few small black spines, sometimes without these; front femur with an irregular row of spines below, larger and smaller mixed and toward the tip on the inner side two or three longer ones; front tibia straight, with a uniform row of nearly erect, even, small spines on inner side; middle femora long and slender, a little bowed; hind femora also long, not so slender, beyond the middle with numerous dense, curved bristles below; the femur tapers rapidly near the tip, almost excised below; all the claws and pulvilli small. Wing narrow, almost hyaline, unspotted, veins blackish. Abdomen bright green, with two long, brownish lamellæ projecting forward underneath, about half as long as the abdomen; fourth sternite bent forward in a V-shape. Length, $3.2 \mathrm{~mm}$.; of wiug, $4 \mathrm{~mm}$.

Female. Face wider than in male, but still narrowed below the antennæ; about ffteen postorbitals on a side; hairs on palpi blackish; a few pale microscopic hairs on sternopleura. Length, $4.9 \mathrm{~mm}$; of wing, $5.4 \mathrm{~mm}$.

Forty specimens, both sexes: Craig's Mt. Idaho (type), June, 1894; Moscow, Idaho, May 3, 1895; Potlatch, Idaho, June 20, 1907; Troy, Idaho, Sept. 26, 1896; Harrison and Juliaetta, Idaho, and Pullman and Seattle, Wash.

This appears to be the commonest Hydrophorus of the Pacific Northwest.

\section{WALKER's SPECies.}

Under the name of chrysologus on a preceding page I have described a species which may be the one to which Walker gave that name, although there is no great certainty about the matter. His description of glaber offers no characters of significance different from that of chrysologus, except that in the former case he mentions the dark knob of the halteres, while in the latter he calls the halteres yellow, very possibly overlooking an infuscation of the knob. The two spots on the wing occur in both descriptions, and with the item about the halteres include almost all of distinctive importance. I know no spotted-winged species with wholly yellow halteres, though in phoca the question is yet open, owing to the loss of both halteres in the single described specimen. If the face is shining in chrysologus, it might be the same as algens, but the ambiguous expression used seems to indicate an opaque face: "head covered with golden bloom, 
which is paler and brighter toward the mouth." The two descriptions of Walker may really refer to the same species, assuming that the brown spot on the knob of the halteres was overlooked in glaber.

Walker's alboflorens seems to approach pirata, having infuscated halteres and unspotted wings, but so many characters are omitted or vaguely mentioned that a decision is impossible.

His viridiflos has been identified with my intentus, but as I understand the expressions used, it is much more nearly related to aestuum, a widely different species. At least it is a small eastern species with the wings pale at the base.

These conclusions will show the uselessness of trying to "do something" with Walker's names. If anything, I have gone too far in assuming that I have identified one species. An examination of Walker's types is the only process that will settle the matter; even that will have only a bibliographical value, and will not advance entomology in the least, assuming that we already know all of his species under some name, which is highly probable. I have heard of one entomologist who in recent years did in fact examine a part of Walker's types of Dolichopodidæ, and who had the self-restraint on coming home to say nothing about what he found, deeming it best not to disturb existing nomenclature. And he is a man who has contributed vastly to entomology in more than one order.

\section{THE DIPTEROUS GENUS DIOSTRACUS LOEW.}

(Pl. 8.-figs. 15-18.)

BY J. M. AldRich,

The University of Idaho, Moscow, Ida.

The genus Diostracus was founded by Loew in his Neue Beitrâge, VIII, 43, 1861, and redescribed in Monographs, II, 120, 1864; the entire second notice is merely a translation of the first, both as to the genus and the single species, with the addition of one or two unimportant comments. ${ }^{1}$ The typical and sole species, prasinus, was collected by Osten Sacken in New York, presumably near New York City. It has apparently not been collected since

\footnotetext{
1 Note.-On page 122 of the monograph, the expression regarding the middle tarsi, " the first joint about as long as the other three taken together," should have been translated "the first joint about as long as the following three," etc.
} 

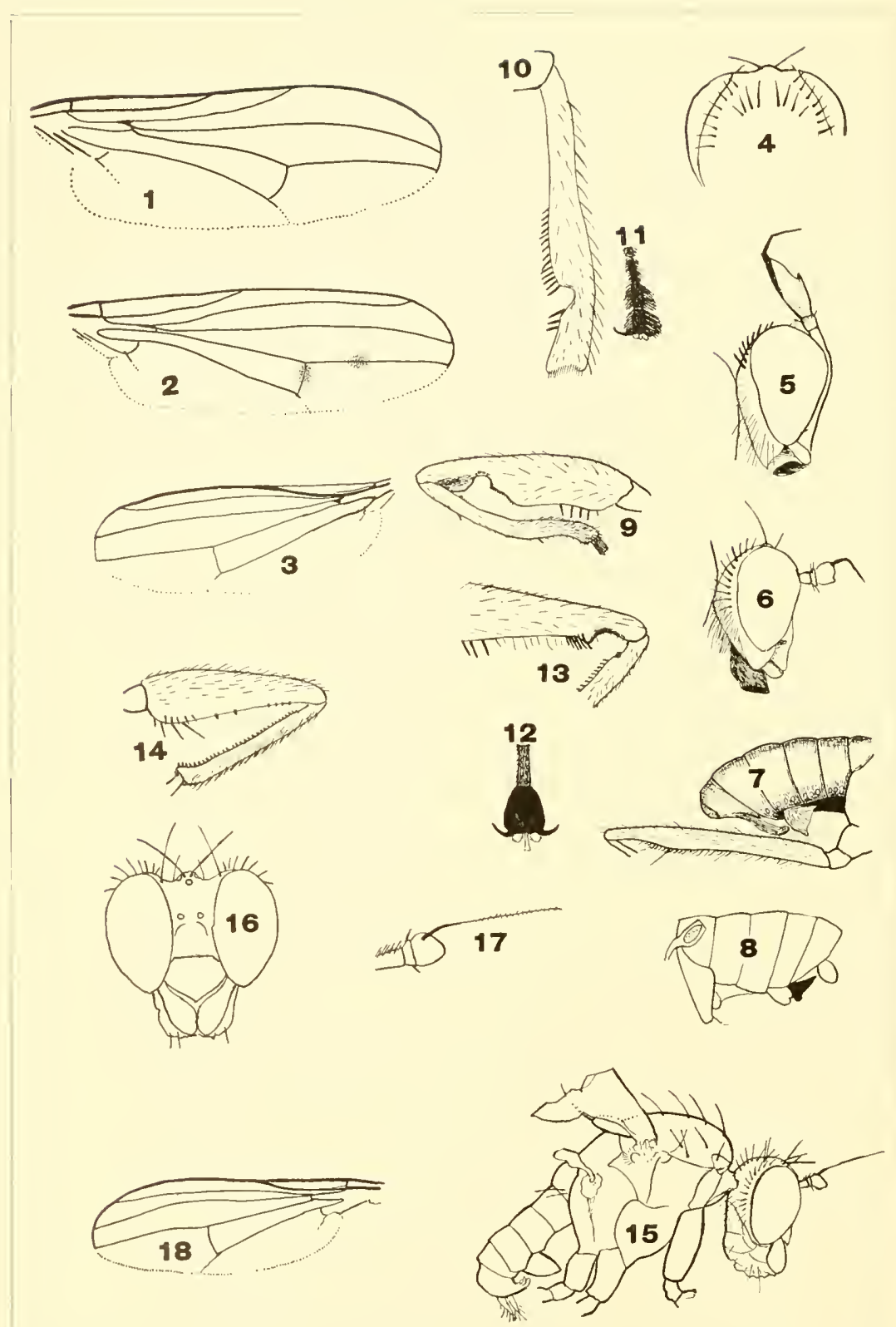

ALDRICH. - NORTH AMERICAN HYDROPHORUS AND DIOSTRACUS. 

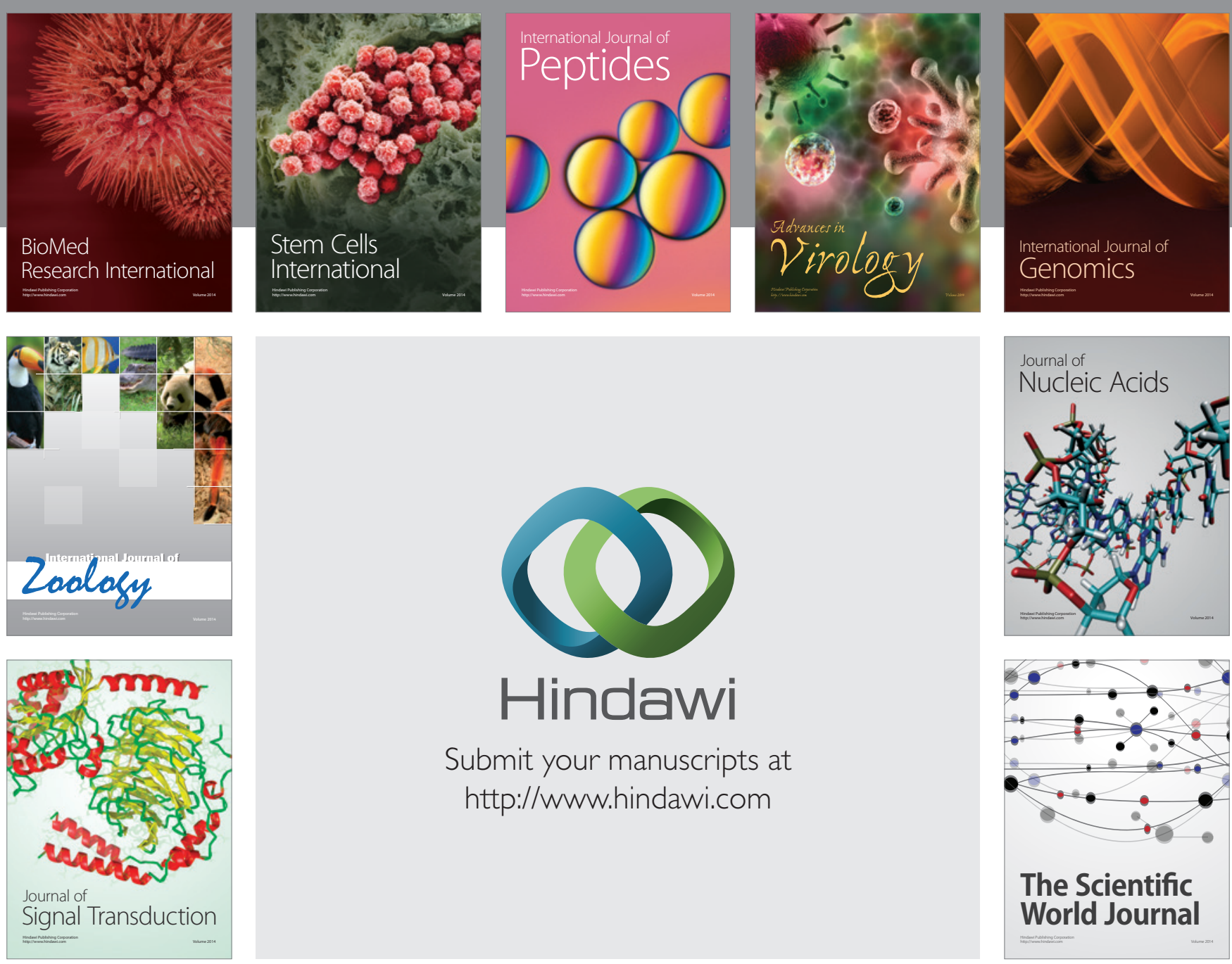

Submit your manuscripts at

http://www.hindawi.com
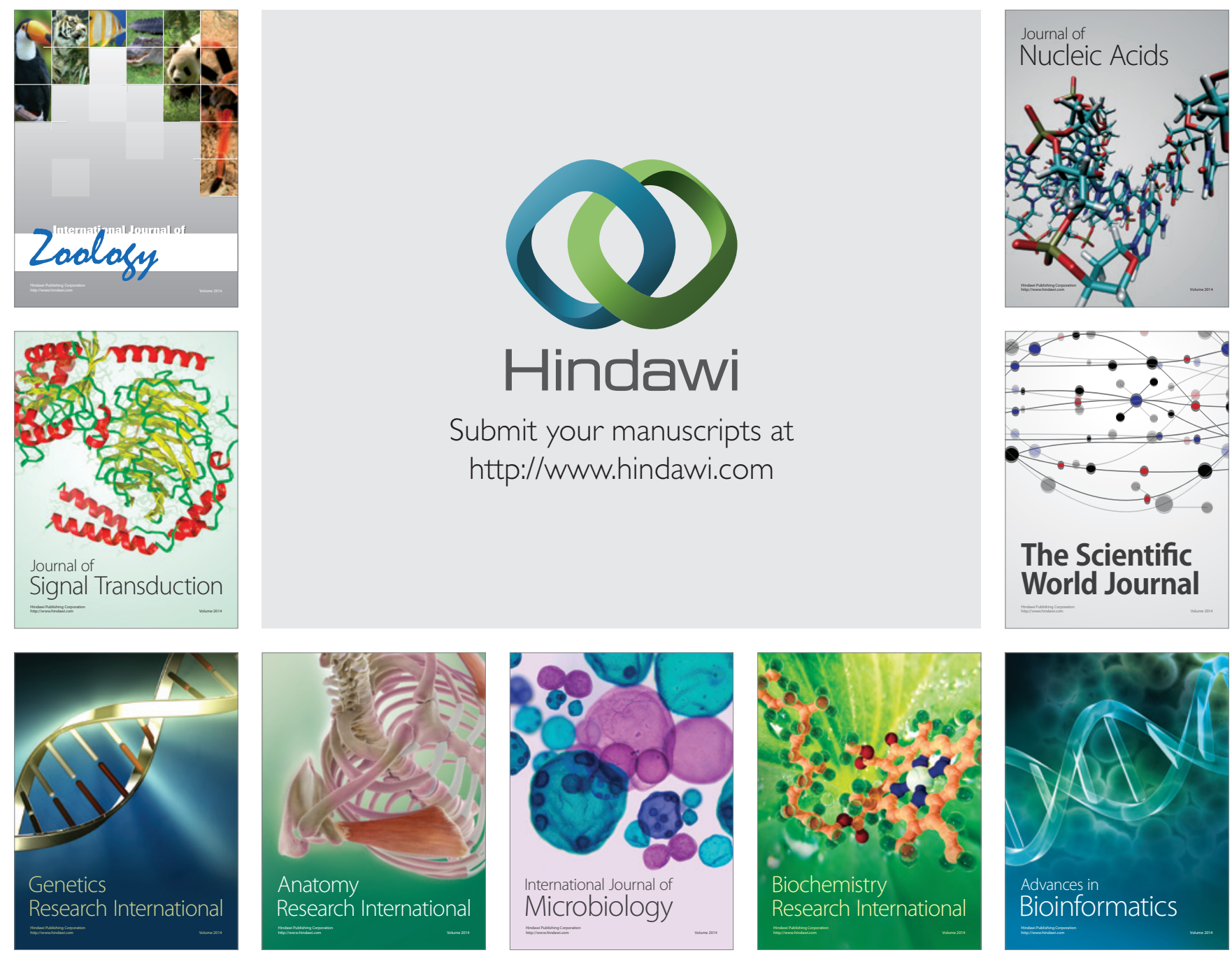

The Scientific World Journal
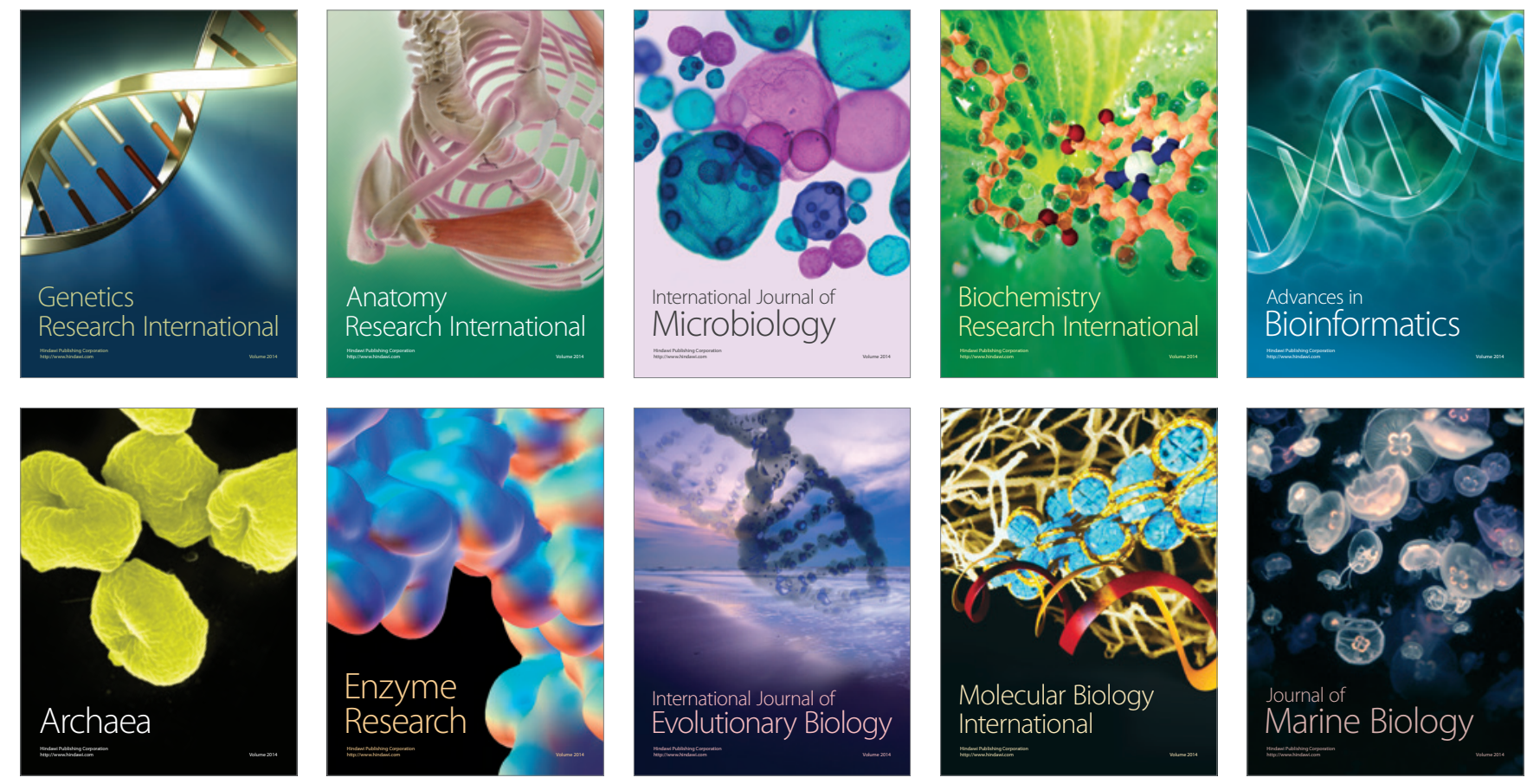